\title{
The Moderating/Mediating Effect of Relationships among Citizenship Behavior, Social Reflection, and Safety Behavior
}

\author{
Chaur-Luh Tsai*, Chun-Pong Wong, Chien-Chang Chou \\ Department of Shipping Technology, National Kaohsiung University of Science and Technology, Taiwan \\ Email: *chaurluh@nkust.edu.tw
}

How to cite this paper: Tsai, C.-L., Wong, C.-P. and Chou, C.-C. (2019) The Moderating/Mediating Effect of Relationships among Citizenship Behavior, Social Reflection, and Safety Behavior. Open Journal of Social Sciences, 7, 241-261.

https://doi.org/10.4236/jss.2019.78017

Received: July 10, 2019

Accepted: August 18, 2019

Published: August 21, 2019

Copyright ( 2019 by author(s) and Scientific Research Publishing Inc. This work is licensed under the Creative Commons Attribution International License (CC BY 4.0). http://creativecommons.org/licenses/by/4.0/

\begin{abstract}
Most extant research has focused on antecedent and consequence factors of citizenship behavior (CB) within organizations. The long-term lifetime effect of $\mathrm{CB}$ has rarely been researched. This study employed a questionnaire survey to collect respondents' perspectives of individual $\mathrm{CB}$ at different life stages. EFA was applied to explore the primary components of $\mathrm{CB}$, i.e., altruism, conscientiousness, sportsmanship, and civic virtue. ANOVA and SEM were performed to examine the hypotheses in this study. The results demonstrated that CBs were influenced by gender, work status, and work experience. CBs also exerted a positive effect on safety behavior, although this effect was mediated by social reflection. Research theory and implementations were discussed.
\end{abstract}

\section{Keywords}

Mediating Effect, Citizenship Behavior, Social Reflection, Safety Behavior

\section{Introduction}

"Citizenship behavior (CB)" refers to individuals collectively demonstrating positive efforts to improve organizational performance beyond their employment requirements [1]. Bolino et al. [2] pointed out that $\mathrm{CB}$ enhance firm functioning by contributing to the development of social capital in organizations; specifically, they contribute to the creation of structural, relational, and cognitive forms of social capital. In other words, the motives behind the willingness to cooperate stem not only from an individual's basic commitment that brings voluntary compliance with organizational goals, but also from the expectancy of collective satisfaction. An organization will benefit from employees with better organiza- 
tional citizenship behavior (OCB), and it has been shown to increase productivity, efficiency and customer satisfaction, and reduce costs and rates of turnover and absenteeism [3]. Thus, CB is considered to be a critical issue in organizations.

In recent decades, researchers focused more on identification of antecedent and consequence factors of OCB [3] [4] [5] [6] [7]. However, OCB is behavior performed within a dedicated organization, which cannot be cultivated in the short-term. The extant literature also comprises investigations of behavioral influence factors from different domains, including culture [8]-[13], personality [4] [14] [15] [16] [17], leadership [18], organization climate [18] [19], and OCB [20] [21] [22] [23] [24]. Even though useful results have been obtained, large research gaps remain. For example, existing studies provided insufficient evidences or ignored long-term influences on behaviors, because all of the findings concerned behaviors presented during the short period of study.

However, it is well-known that behavior is cultivated through education and interaction with the environment from childhood onwards. When behavior has been formed and presents in daily life, it then tends to be resistant to change, as expressed in the Chinese proverb, "Change easily, nature is hard to move". Moreover, Hofstede [9] claims that cultural differences exert a profound influence on individuals' attitudinal tendencies. He highlights the cultural difference concept, and defines culture as dissimilarities in collective values of society [9]. Mole [12] argues that culture is a combination of various influences that encourage individuals to do things in a certain manner. Therefore, individuals' attitudinal patterns could be influenced by culture [25].

All managers want members within their organizations to achieve excellent performance. Human resource managers are particularly responsible to recruit the most appropriate people to join their organization, in order to form good $\mathrm{OCB}$ and to maintain superior performance. Consequently, this study focuses on the influence of $\mathrm{CB}$ on performance and how it affects performance. The remainder of this paper is organized into five sections. A literature review is presented in the second section, which discusses previous research regarding the theory of OCB, behavioral influence factors, and their results. The third section describes the research methodology, including the questionnaire designed, target sampling, analysis techniques, etc. The results of data analyses are shown in the fourth section. Finally, the study's findings are discussed in the final section.

\section{Literature Review}

CB was defined as an employee's sense of intentional involvement in organizational activities without expecting any type of benefits [26]. It was derived from the "innovative and spontaneous behavior" concept [27] [28], and modified Barnard's [1] conception by pointing out supra-role behavior in an organization's social relationships with its employees [20] [29]. These concepts suggested 
that $\mathrm{CB}$ requires discretionary functions in an effort to augment organizational effectiveness without taking individual benefits into account [23] [26] [30] [31]. It constitutes an expression of one's compassion, sacrifice and volunteering spirit, carried out willingly without expecting reciprocity. In this study, $\mathrm{CB}$ is defined as behavior of people performed in ordinary life, because the behavior cannot be cultivated in a short period of time.

Podsakoff and colleagues [29] identified over 30 different forms of CB. Recognizing the large overlap and similarity among CBs, the researchers categorized the behaviors into seven themes, including helping behaviors, sportsmanship, organizational loyalty, organizational compliance, individual initiative, civic virtue, and self-development [28]. Organ [23] identifies five categories of discretionary behavior, and explains how each assists to improve efficiency in the organization. They are called OCB [23] [32] and comprise altruism, conscientiousness, sportsmanship, courtesy, and civic virtue.

OCB is considered to comprise a special role that members of an organization are expected to perform. Organizations could not survive or prosper without their members behaving as good citizens by engaging in many types of positive behaviors [23]. Moreover, previous literature found that culture differences have impacts on OCB [10] [11]. Lin and Ho [11] reported that people with a collectivist inclination engage in OCB more positively, since group harmony and unity are primary tenets of collectivism. Previous studies [33] [34] [35] [36] [37] also found that results of interactions with the environment will direct employees' emotions to enhance behavior within the organization. Tziner and Sharoni's [37] study demonstrated that perceived organizational justice affects employees' behavior, satisfaction, esteem, loyalty, and commitment to the organization and its leaders. The results imply that OCB is a by-product of organizational justice, which contributes to organizational success and expresses employees' loyalty and commitment to the organization's goals. These findings indicate that OCB is positively affected by culture and the environment.

Numerous investigations suggested that OCB comprises two factors based on the target of the behavior, including organizationally-targeted and interpersonally-targeted [24] [38] [39]. Organizationally-targeted behaviors, such as augmenting the reputation of the organization, are referred to as organizational; whereas, interpersonally-targeted $\mathrm{OCB}$, such as assisting to acclimate a new employee, are referred to as interpersonal. This study aimed to determine precisely how to identify the optimal person with better CB before he or she enters an organization. The author applies the following four interpersonal targeted behaviors as CB: altruism, conscientiousness, civic virtue, and sportsmanship. Therefore, the hypothesis postulated as:

H1: CB has a positive effect on safety behavior.

Exception considering the behavior to be predicted by $\mathrm{CB}$, it may also be affected by certain social reflection factors, such as personal perspective and attitude. According to reflection theory, our knowledge reflects the real world. Previous researchers [40] [41] suggested that all ideas derive from experiences of the 
external world. Our sense of what is the correct behavior to perform is generated through a lifetime of learning from experience [34] [42] [43] [44] [45] [46]. Accordingly, our ideas resemble (or reflect) the objects that give rise to them, and are transformed into exhibited behavior. The hypothesis postulated as:

$\mathrm{H} 2$ : Social reflection factors have a positive effect on safety behavior.

However, Bolino et al. [47] indicated that existing research does not explain the fundamentally different reactions that people have to their experiences of engaging in OCB. This study considered CB to be moderated by the effects of some external factors on performance [44] [47] [48] [49] [50]. The hypothesis postulated as:

H3: CB has a positive effect on social reflection factors.

H4: Social reflection factors modulate the effect of CB on safety behavior.

The research model is shown in Figure 1.

\section{Methodology}

\subsection{Questionnaire Design}

The study aimed to determine the role that CB plays in performance and its external influence in different life stages. A questionnaire survey was administered to collect data to examine the effect of $\mathrm{CB}$ on traffic safety performance. The research steps employed in this study included instrument development, exploratory factor analysis, variance analysis, and structural equation modeling. The questionnaire was designed according to the literature [23] [29] [47], and the results of observation and interviews to collect data of target citizens' perceptions were based on the recommendation of Churchill and Iacobucci [51]. The measures were designed according to the dimensions of $\mathrm{CB}$, i.e., altruism, conscientiousness, civic virtue and sportsmanship, and safety perspective and work attitude were utilized as social reflection factors. Because the current study focuses on examination the behavior changing for long period of lifetime, the common safety behavior, traffic safety behavior, is employed as safety performance that all people are encountering in daily life. Therefore some individual common traffic safety behavioral attributes were employed to measure the

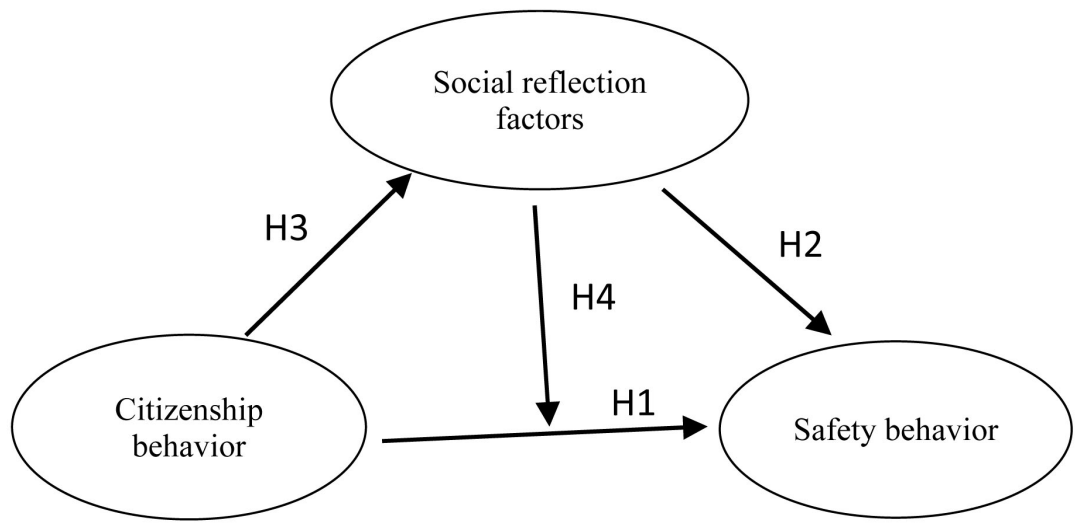

Figure 1. Research conceptual model. 
change of safety performance. They presented in the form of "I reduce speed as I approach the block even without any traffic", "I always follow traffic regulations", "I always follow the instruction of traffic signals", and "I am never against the traffic lane (I always keep in the right traffic lane)". At the end of 2015, the author conducted a pilot test to verify and modify the wording and question for suitability for the present study. The questionnaire comprised three sections, including an introduction, questions, and demographic information (see Appendix Table A1). The questions were measured on a five-point Likert scale, ranging from (1) "strongly disagree" to (5) "strongly agree".

\subsection{Sampling}

The study focused on exploring the effects of CB on safety performance among different life stages in Taiwan. The respondents are focusing in different life stage from the secondary school to college and after graduating with a job. The questionnaire was conveniently distributed to the student of junior and senior high school who visited the campus of NKMU in 2016, the students of the maritime college, and the seafarers who were attending refresher training at the seafarers' training center of NTOU and NKMU in Taiwan. The survey was conducted from May 2016 to April 2017. In total, 850 questionnaires were distributed to the target respondents, and 668 were returned. After discarding 102 incomplete questionnaires, 566 were considered valid, constituting a completion rate of $66.6 \%$.

\subsection{Data Analysis Methodology}

According to previous research [18] [19], an exploratory factor analysis can reduce a large set of variables to a smaller set of underlying dimensions, which assists to detect the presence of meaningful patterns among the original variables. Therefore, to ensure that the data of $\mathrm{CB}$ are suitable for performing a factor analysis, the Bartlett Test of Sphericity must be significant and the Kaiser-Meyer-Olkin value must be above 0.8 [52]. In addition, a minimum of five subjects per variable or a sample of 100 is requisite for a factor analysis [53]. The criteria include eigenvalues over 1 and a minimum of $5 \%$ variance per factor. Moreover, the scree plot is commonly utilized to extract factors. Factors with loadings of 0.40 or more are retained [54] [55].

Reliability is determined as the ratio of true score variance to observed score variance [52] [56], which could be assessed in three forms: test-retest, alternate-form, and internal consistency [57]. Generally, Cronbach's alpha is used to measure internal consistency reliability among a group of items combined to form a single scale; levels of 0.7 or more are considered reliable in basic research [55] [57] [58]. Since a moderating/mediating effect occurs when some variables are combined, structure equation modeling (SEM) was finally performed to examine the effects of relationships among $\mathrm{CB}$, social reflection, and safety behavior in this study. 


\section{Results of Data Analysis}

\subsection{Respondents' Profiles}

Respondents' characteristics in terms of gender, age, education level, work status, specialized skills, and sea age (work experience after graduating) were elicited to ascertain whether respondents' perceptions were influenced by these characteristics. Among the respondents, 457 were male and 109 were female (see Table 1). Regarding age, there were 64 respondents younger than 15,344 were aged between 16 and 20, 37 respondents were aged between 21 and 25, 58 were aged between 26 and 30, 29 were aged between 31 and 35, and 34 were older than 35. Concerning education level, 70 respondents indicated that they were in secondary school, 276 were in high school, 125 respondents were in college/university, and 95 respondents had completed university education. Regarding work status, 44 respondents stated that they were not working, 414 were students, and 108 respondents were working on shore or serving onboard. Concerning specialized skills, 123 responded that they had none, 220 were specialized in navigation, 215 were specialized in engine, and eight responded "others". Regarding sea age (work experience after graduating), most respondents (438, 77.4\%) had work experience of less than one year, 63 between one and three years, 36 between four and six years, and 29 respondents had six or more years.

Table 1. Respondents' profile.

\begin{tabular}{|c|c|c|c|}
\hline \multicolumn{2}{|c|}{ Characteristics } & \multirow{2}{*}{$\begin{array}{c}\text { Frequency } \\
457\end{array}$} & \multirow{2}{*}{$\begin{array}{c}\text { Percentage \% } \\
80.7\end{array}$} \\
\hline Gender & Male & & \\
\hline & Female & 109 & 19.3 \\
\hline \multirow[t]{6}{*}{ Age } & $<15$ & 64 & 11.3 \\
\hline & $16-20$ & 344 & 60.8 \\
\hline & $21-25$ & 37 & 6.5 \\
\hline & $26-30$ & 58 & 10.2 \\
\hline & $31-35$ & 29 & 5.1 \\
\hline & $>35$ & 34 & 6.0 \\
\hline \multirow[t]{4}{*}{ Life stage } & Secondary school & 70 & 12.4 \\
\hline & High school & 276 & 48.8 \\
\hline & College/university & 125 & 22.1 \\
\hline & Graduated & 95 & 16.8 \\
\hline \multirow[t]{3}{*}{ Work status } & None & 44 & 7.8 \\
\hline & Study in school & 414 & 73.1 \\
\hline & Serve onboard or onshore & 108 & 19.1 \\
\hline \multirow[t]{4}{*}{ Specialized skills } & None & 123 & 21.7 \\
\hline & Navigation & 220 & 38.9 \\
\hline & Engine & 215 & 38.0 \\
\hline & Others & 8 & 1.4 \\
\hline \multirow[t]{4}{*}{ Sea age } & $<1$ & 438 & 77.4 \\
\hline & $1-3$ & 63 & 11.1 \\
\hline & $4-6$ & 36 & 6.4 \\
\hline & $>6$ & 29 & 5.1 \\
\hline
\end{tabular}




\subsection{Exploratory Factor Analysis}

\subsubsection{Citizenship Behavior}

Exploratory factor analysis (EFA) is commonly employed in exploratory studies, and was conducted to develop and evaluate measurement dimensions in this study. In order to detect the presence of meaningful patterns among original variables and extract the main factors, principal component analysis with Varimax rotation was applied to reduce the 15 perceptive attributes of CB into a smaller and more manageable set of underlying dimensions. A Kaiser-Meyer-Olkin value of 0.865 indicated that the data were suitable for performing a factor analysis, and the Bartlett Test of Sphericity $\left[\chi^{2}=2607.17, \mathrm{P}<0.001\right]$ indicated that correlations existed among some of the response categories. Eigenvalues greater than one were used to determine the number of factors in each data set [51] [59] [60]. Results presented in Table 1 indicate that four factors accounted for approximately $70.41 \%$ of the total variance, and thus represented the primary component of this study. Moreover, an examination of loading factors in Table 2 shows that all items on each of the factors were 0.5 or higher, indicating acceptable

Table 2. Exploratory factor analysis with Varimax rotation results of $\mathrm{CB}(\mathrm{N}=566)$.

\begin{tabular}{|c|c|c|c|c|c|}
\hline & Measures & $\mathrm{F} 1$ & $\mathrm{~F} 2$ & F3 & F4 \\
\hline V8 & $\begin{array}{l}\text { I actively express opinions that are not required, } \\
\text { but that help the organization function. }\end{array}$ & 0.835 & 0.094 & 0.172 & 0.146 \\
\hline V7 & $\begin{array}{l}\text { I actively attend activities that are not required, but } \\
\text { that help enhance the image of the organization. }\end{array}$ & 0.751 & 0.111 & 0.235 & 0.221 \\
\hline V9 & $\begin{array}{l}\text { I consider that all members are responsible for the } \\
\text { development and reputation of the organization. }\end{array}$ & 0.731 & 0.250 & 0.181 & 0.100 \\
\hline V10 & $\begin{array}{l}\text { I keep abreast of changes/developments } \\
\text { in the organization. }\end{array}$ & 0.730 & 0.251 & 0.151 & -0.001 \\
\hline V12 & I focus on the positive aspects of my responsibility. & 0.296 & 0.796 & 0.173 & 0.060 \\
\hline V11 & $\begin{array}{l}\text { I make the necessary improvements } \\
\text { if the critique is justified. }\end{array}$ & 0.190 & 0.774 & 0.216 & 0.082 \\
\hline V15 & I conform to all obligations with great care. & 0.117 & 0.743 & 0.156 & 0.252 \\
\hline $\mathrm{V} 2$ & I take time out of my day to help train newcomers. & 0.218 & 0.054 & 0.851 & 0.107 \\
\hline V3 & $\begin{array}{l}\text { I share my knowledge and expertise } \\
\text { with other coworkers. }\end{array}$ & 0.167 & 0.316 & 0.744 & 0.082 \\
\hline V1 & $\begin{array}{l}\text { I support coworkers/classmates } \\
\text { who have problems at work. }\end{array}$ & 0.245 & 0.234 & 0.733 & 0.090 \\
\hline V13 & I do not complain about trivial matters. & 0.160 & 0.069 & 0.066 & 0.864 \\
\hline \multirow[t]{5}{*}{ V14 } & I usually tolerate minor imperfections. & 0.121 & 0.233 & 0.144 & 0.808 \\
\hline & Eigenvalues & 4.95 & 1.26 & 1.20 & 1.04 \\
\hline & $\%$ of Variance & 22.00 & 17.91 & 17.34 & 13.16 \\
\hline & Cumulative & 22.00 & 39.91 & 57.25 & 70.41 \\
\hline & Reliability & 0.83 & 0.78 & 0.78 & 0.69 \\
\hline
\end{tabular}

Note: F1 = Conscientiousness; F2 = Civic Virtue; F3 = Altruism; F4 = Sportsmanship. 
interpretability [52] [61]. Four factors were subsequently found to underlie CB in this study based on the participants' responses.

Factor 1, a conscientiousness dimension, contains four items referring to the respondents' perceptions of $\mathrm{CB}$ concerning helping others; therefore, it was labeled conscientiousness. Its eigenvalue was 4.95 and accounted for $22.00 \%$ of the total variance. The value of Cronbach's alpha was 0.83 , and values greater than 0.7 were acceptable.

Factor 2, a civic virtue dimension, comprises three items relating to civic virtue perception; therefore, it was labeled civic virtue. The eigenvalue was 1.26 and accounted for $17.91 \%$ of the total variance. The value of Cronbach's alpha was 0.78 , and values greater than 0.7 were acceptable.

Factor 3, an altruism dimension, consists of three items related to altruism perceptions of the respondents; therefore, it was labeled altruism. It accounted for $17.34 \%$ of the total variance, and the eigenvalue was 1.20 . The Cronbach's alpha was 0.78 , and values greater than 0.7 were acceptable.

Factor 4, a sportsmanship dimension, contains two items related to sportsmanship perception; therefore, it was labeled sportsmanship. It accounted for 13.16\% of the total variance, and the eigenvalue was 1.04 . The Cronbach's alpha was 0.69 , which was reasonable since it has only two subset questions [62].

\subsubsection{Social Reflection Attributes}

Factor analysis with Varimax rotation was conducted to identify the underlying dimensions of social reflection perceptive attributes. A Kaiser-Meyer-Olkin value of 0.814 indicated that the data were suitable for conducting factor analysis, and the Bartlett Test of Sphericity $\left[\chi^{2}=1739.82, P<0.001\right]$ suggested that correlations existed among some of the response categories. Results, as shown in Table 3, revealed that two factors, namely, safety perspective and work attitude, accounted for approximately $63.69 \%$ of the total variance, and thus represented all of the social reflection attributes in this study.

Table 3. EFA with Varimax rotation results of social reflection attributes $(\mathrm{N}=566)$.

\begin{tabular}{|c|c|c|c|}
\hline & Measures & F1 & F2 \\
\hline V16 & $\begin{array}{l}\text { I consider it as a chance for self-enhancement } \\
\text { when I encounter a problem during work. }\end{array}$ & 0.815 & 0.148 \\
\hline V17 & I consider it as a challenge when I encounter a problem during work. & 0.814 & 0.143 \\
\hline V18 & I always do my best to complete my assignment. & 0.786 & 0.157 \\
\hline V19 & I always complete my work efficiently. & 0.777 & 0.099 \\
\hline V20 & I always complete my work by the due time. & 0.695 & 0.236 \\
\hline V26 & It is important to secure my seat belt when I sit in a car. & 0.138 & 0.794 \\
\hline V25 & It is important to wear a helmet when I ride a bicycle/motorcycle. & 0.145 & 0.794 \\
\hline V21 & $\begin{array}{l}\text { It is important to wear proper personal protective } \\
\text { equipment when I work/exercise (biking or skating). }\end{array}$ & 0.180 & 0.772 \\
\hline & Eigenvalues & 3.66 & 1.43 \\
\hline & $\%$ of Variance & 38.81 & 24.88 \\
\hline & Cumulative & 38.81 & 63.69 \\
\hline & Reliability & 0.85 & 0.72 \\
\hline
\end{tabular}

Note: F1 = Work a note: F1 = Work attitude; F2 = Safety perceptive. 
Factor 1 comprised five items, and was labeled work attitude. Its eigenvalue was 3.66 and accounted for $38.81 \%$ of total variance. The value of Cronbach's alpha was 0.85 , and values greater than 0.7 were acceptable.

Factor 2 consisted of three items which were related to perceptions of safety, and this factor was labeled as safety perceptions. The eigenvalue was 1.43 , and it accounted for $24.88 \%$ of total variance. The Cronbach's alpha was 0.72 , and values greater than 0.7 were acceptable.

\subsection{ANOVA Test}

One-way ANOVA was utilized to identify whether perceived differences in dimensions of $\mathrm{CB}$ existed between various groups based on demographic variables, such as age, education level, work status and experience, and specialized skills. The results are presented in Tables $4-6$. The results in Table 4 revealed that gender perceptions did not significantly differ regarding the dimensions of conscientiousness and civic virtue. However, significant differences were identified between gender perceptions towards the two remaining dimensions, i.e., altruism and sportsmanship, at the 5\% significance level. Concerning male respondents, Table 4 shows that they have a lower mean score (3.89) on altruism, but have a higher mean score (3.54) on sportsmanship, compared to the mean scores of female respondents on these two dimensions, which were 4.03 and 3.34, respectively. These results indicated that the different genders perform different CBs.

Table 4. Comparisons of differences in respondents' perceptions of the four CB dimensions by gender.

\begin{tabular}{cccccc}
\hline \multirow{2}{*}{ Dimensions } & \multicolumn{2}{c}{ Male $(\mathrm{N}=457)$} & \multicolumn{2}{c}{ Female $(\mathrm{N}=109)$} & \multirow{2}{*}{ F-value } \\
\cline { 2 - 5 } & Mean & S.D. & Mean & S.D. & \\
\hline Altruism & 3.89 & 0.59 & 4.03 & 0.56 & $4.93^{\star}$ \\
Conscientious & 3.55 & 0.71 & 3.63 & 0.66 & 1.16 \\
Sportsmanship & 3.54 & 0.78 & 3.34 & 0.71 & $6.19^{*}$ \\
Civic Virtue & 4.12 & 0.63 & 4.11 & 0.56 & 0.04 \\
\hline
\end{tabular}

Note: ${ }^{*} \mathrm{p}<0.05$.

Table 5. Comparisons of differences in respondents' perceptions of the four CB dimensions by work status.

\begin{tabular}{ccccccccc}
\hline & \multicolumn{2}{c}{ 1) No } & \multicolumn{2}{c}{ 2) In School } & \multicolumn{2}{c}{ 3) Working } & & \\
\cline { 2 - 7 } Dimensions & \multicolumn{2}{c}{$(\mathrm{N}=44)$} & \multicolumn{2}{c}{$(\mathrm{N}=414)$} & \multicolumn{2}{c}{$(\mathrm{N}=108)$} & \multirow{2}{*}{ F-value } & Sheffe \\
\cline { 2 - 7 } & Mean & S.D. & Mean & S.D. & Mean & S.D. & & \\
\hline Altruism & 3.91 & 0.61 & 3.89 & 0.60 & 4.06 & 0.53 & $3.86^{*}$ & $(2,3)$ \\
Conscientious & 3.64 & 0.69 & 3.52 & 0.71 & 3.67 & 0.64 & 2.15 & \\
Sportsmanship & 3.42 & 0.75 & 3.48 & 0.79 & 3.59 & 0.70 & 1.11 & \\
Civic Virtue & 4.14 & 0.75 & 4.08 & 0.62 & 4.27 & 0.48 & $4.50^{*}$ & $(2,3)$ \\
\hline
\end{tabular}

Note: ${ }^{\star} \mathrm{p}<0.05$. 
Table 6. Comparison of differences in respondents' perceptions of the four CB dimensions by work experience (sea age).

\begin{tabular}{|c|c|c|c|c|c|c|c|c|c|c|}
\hline \multirow[t]{2}{*}{ Dimensions } & \multicolumn{2}{|c|}{$\begin{array}{c}1)<1 \\
(\mathrm{~N}=438)\end{array}$} & \multicolumn{2}{|c|}{$\begin{array}{c}\text { 2) } 1-3 \\
(\mathrm{~N}=63)\end{array}$} & \multicolumn{2}{|c|}{$\begin{array}{c}\text { 3) } 4-6 \\
(\mathrm{~N}=36)\end{array}$} & \multicolumn{2}{|c|}{$\begin{array}{c}4)>6 \\
(N=29)\end{array}$} & \multirow{2}{*}{$\begin{array}{c}\mathrm{F} \\
\text { value }\end{array}$} & \multirow[t]{2}{*}{ Sheffe } \\
\hline & Mean & S.D. & Mean & S.D. & Mean & S.D. & Mean & S.D. & & \\
\hline Altruism & 3.88 & 0.60 & 3.94 & 0.50 & 4.22 & 0.41 & 4.08 & 0.70 & $4.44^{\mathrm{b}}$ & $(1,3)$ \\
\hline Conscientious & 3.54 & 0.72 & 3.55 & 0.55 & 3.81 & 0.66 & 3.65 & 0.75 & 1.92 & \\
\hline Sportsmanship & 3.48 & 0.79 & 3.42 & 0.60 & 3.64 & 0.81 & 3.81 & 0.60 & 2.31 & \\
\hline Civic Virtue & 4.08 & 0.64 & 4.16 & 0.40 & 4.40 & 0.48 & 4.23 & 0.62 & $3.43^{\mathrm{a}}$ & $(1,3)$ \\
\hline
\end{tabular}

Note: ${ }^{\mathrm{a}} \mathrm{p}<0.05 ;{ }^{\mathrm{b}} \mathrm{p}<0.01$.

Table 5 presents the results obtained from comparing respondents' perceptions of CB dimensions by work status, namely, no work, in school, and working. Respondents who were working had the highest mean score on the altruism dimension (mean $=4.06$, S.D. $=0.53)$ and civic virtue dimension $($ mean $=4.27$, S.D. $=0.48$ ); whereas, respondents in school had the lowest mean scores on these two dimensions of 3.89 and 4.08, respectively. In general, the respondents in school tended to experience a peaceful and stable environment, while people who had left school and been working in different workplaces tended to experience fluctuating environments. The results indicated that $\mathrm{CB}$ is significantly affected by the environment.

Table 6 shows the results obtained from comparing respondents' perceptions of the four $\mathrm{CB}$ dimensions by work experience onboard. The results indicated that respondents' perceptions differed significantly in the dimensions of altruism and civic virtue. Regarding the altruism dimension, respondents with experience between four and six years had the highest mean score $($ mean $=4.22$, S.D. $=$ 0.41 ), followed by experience longer than six years (mean $=4.08$, S.D. $=0.70$ ), experience between one and three years (mean $=3.94$, S.D. $=0.50$ ), and less than one year $($ mean $=3.88$, S.D. $=0.60)$. Concerning the civic virtue dimension, respondents with experience between four and six years had the highest mean score (mean $=4.40$, S.D. $=0.48)$, as well. This was followed by experience longer than six years $($ mean $=4.23$, S.D. $=0.62)$, experience between one and three years $($ mean $=4.16$, S.D. $=0.40)$, and less than one year $($ mean $=4.088$, S.D. $=0.64)$. The results show that the respondents with less work experience had a lower mean score, while the respondents who had more work experience had a higher mean score on the two dimensions of altruism and civic virtue. These results provided evidence that work experience has a significant influence on $\mathrm{CB}$.

\subsection{Path Analysis}

\subsubsection{Test of the Proposed Structural Equation Modeling}

After ANOVA testing, structure equation modelling (SEM) was applied to examine the path effects among different models with various independent and dependent variables, including $\mathrm{CB}$, safety perspective, work attitude, and safety 
behavior. The results of fitness of the measurement models are displayed in Table 7. Because the chi-square $\left(\chi^{2}\right)$ value is sensitive to sample size [63] [64], model examinations were based on other fitness indices, including chi-square ratio $\left(\chi^{2} / \mathrm{df}\right)$, root mean square residual (RMR), root mean square error of approximation (RMSEA), goodness-of-fit index (GFI), adjusted goodness-of-fit index (AGFI), comparative fit index (CFI), and the Tucker Lewis Index (TLI) [65] [66] [67] [68]. The results showed that the chi-square ratios ( $\left.\chi^{2} / \mathrm{df}\right)$ were all less than four, and the value of RMR and RMSEA were less than 0.03 and 0.07 , which were all smaller than the threshold value of 0.05 and 0.08 , respectively, and were acceptable. The other fitness indices values, i.e., GFI, AGFI, CFI and TLI, were all greater than the recommended level of 0.90 (see Table 7). In addition to these fitness indices, the items of each dimension were examined based on certain criteria, including standardized residuals in absolute terms greater than 2.58 [52] and completely standardized expected changes greater than 0.3 [66]. All of these models had an acceptable model-to-data fit. These fit measures indicated that the hypothesized model fit the data well in each model [69].

\subsubsection{Results of the Hypothesized Relationships}

This study aimed to discern the effects of $\mathrm{CB}$ on safety behavior and the roles that additional factors may play in the full influence model. Therefore, the author first examined the simplest model, which contains the two dimensions of $\mathrm{CB}$ and the explanation of safety behavior. This model has a good model fitness value: a chi-square ratio $\left(\chi^{2} / \mathrm{df}\right)=3.11 ; \mathrm{RMR}=0.021 ; \mathrm{RMSEA}=0.061 ; \mathrm{GFI}=$ 0.98 ; AGFI $=0.95$; CFI $=0.98$; and TLI $=0.97$ (see Model 1 in Table 7). The coefficient $(\beta=0.48, \mathrm{P}<0.01)$ displayed in Model 1 of Table 8 presents the relationship between $\mathrm{CB}$ and safety behavior, which was found to exert a positive effect.

Secondly, an additional factor (i.e., safety perspective) was added into the examining model, which also has a good model fitness value: chi-square ratio $\left(\chi^{2} / \mathrm{df}\right)=2.80 ; \mathrm{RMR}=0.028 ; \mathrm{RMSEA}=0.056 ; \mathrm{GFI}=0.97 ; \mathrm{AGFI}=0.95 ; \mathrm{CFI}=$ 0.97; and TLI $=0.96$ (see Model 2 in Table 7). The coefficient values between CB and safety behavior, between $\mathrm{CB}$ and safety perspective, and between safety perspective and safety behavior were $0.22,0.60$, and 0.44 , respectively, and all coefficients were significant at the 0.01 level (see Model 2 in Table 8). However, the coefficient of the relationship between $\mathrm{CB}$ and safety behavior decreased from 0.48 to 0.22 in this model.

Table 7. The results of the SEM model test.

\begin{tabular}{lccccccccc}
\hline \multicolumn{1}{c}{ Model } & $\chi^{2}$ & DF & Ratio & RMR & RMSEA & GFI & AGFI & CFI & TLI \\
\hline 1) CB-SB & 58.99 & 19 & 3.11 & 0.021 & 0.061 & 0.975 & 0.952 & 0.979 & 0.969 \\
2) CB-SP-SB & 114.62 & 41 & 2.80 & 0.028 & 0.056 & 0.966 & 0.945 & 0.970 & 0.960 \\
3) CB-WA-SB & 165.54 & 51 & 3.25 & 0.024 & 0.063 & 0.954 & 0.930 & 0.962 & 0.950 \\
4) CB-SR-SB & 238.87 & 85 & 2.81 & 0.027 & 0.057 & 0.948 & 0.926 & 0.957 & 0.947 \\
\hline
\end{tabular}

Note: $\mathrm{CB}$ = Citizenship Behavior; $\mathrm{SB}=$ Safety Behavior; $\mathrm{SP}$ = Safety Perspective; $\mathrm{SR}=$ Social Reflection; WA $=$ Work Attitude. 
Table 8. Path examination of the SEM model.

\begin{tabular}{cccccc}
\hline Model & Hypothesis & Paths & Direct effect & Indirect effect & Total effect \\
\hline Model 1 & & $\mathrm{CB} \rightarrow \mathrm{SB}$ & $0.48^{* *}$ & & 0.48 \\
Model 2 & & $\mathrm{CB} \rightarrow \mathrm{SB}$ & $0.22^{* *}$ & 0.26 & 0.48 \\
& & $0.60^{* *}$ & & 0.60 \\
& $\mathrm{CB} \rightarrow \mathrm{SP}$ & $0.44^{* *}$ & & 0.44 \\
Model 3 & $\mathrm{SP} \rightarrow \mathrm{SB}$ & $0.30^{* *}$ & 0.19 & 0.49 \\
& $\mathrm{CB} \rightarrow \mathrm{SB}$ & $0.79^{* *}$ & & 0.79 \\
Model 4 & $\mathrm{CB} \rightarrow \mathrm{WA}$ & $0.24^{*}$ & & 0.24 \\
& $\mathrm{H} 1 \& \mathrm{H} 4$ & $\mathrm{CB} \rightarrow \mathrm{SB} \rightarrow \mathrm{SB}$ & 0.05 & 0.44 & 0.49 \\
& $\mathrm{H} 2$ & $\mathrm{SP} \rightarrow \mathrm{SB}$ & $0.43^{* *}$ & & 0.43 \\
& $\mathrm{WA} \rightarrow \mathrm{SB}$ & $0.23^{* *}$ & & 0.23 \\
& $\mathrm{H} 3$ & $\mathrm{CB} \rightarrow \mathrm{SP}$ & $0.60^{* *}$ & & 0.60 \\
& $\mathrm{CB} \rightarrow \mathrm{WA}$ & $0.79^{* *}$ & & 0.79 \\
\hline
\end{tabular}

Note: ${ }^{*} \mathrm{p}<0.05 ;{ }^{*} \mathrm{p}<0.01 ; \mathrm{CB}=$ Citizenship behavior; $\mathrm{SB}=$ Safety behavior; $\mathrm{SP}=$ Safety perspective; $\mathrm{SR}=$ Social reflection; $\mathrm{WA}=$ Work attitude.

The author then examined the model with three dimensions, including $\mathrm{CB}$, work attitude, and safety behavior. The results are presented in Model 3 of Table 7 and Table 8. This model has a good model fitness value: chi-square ratio $\left(\chi^{2} / \mathrm{df}\right)=3.25 ; \mathrm{RMR}=0.024 ; \mathrm{RMSEA}=0.063 ; \mathrm{GFI}=0.95 ; \mathrm{AGFI}=0.93 ; \mathrm{CFI}=$ 0.96 ; and TLI $=0.95$. The standardized coefficient values between $\mathrm{CB}$ and safety behavior, between $\mathrm{CB}$ and work attitude, and between work attitude and safety behavior were 0.30, 0.79, $(\mathrm{p}<0.01)$, and $0.24(\mathrm{p}<0.05)$, respectively (see Model 3 in Table 8). However, the standardized coefficient of the relationship between $\mathrm{CB}$ and safety behavior decreased from 0.48 to 0.30 in this model, as well. Accordingly, these results constituted evidence that social reflections regarding safety perspective and work attitude play a moderating role when they individually combine with CB to affect safety behavior.

Finally, to provide more evidence to support the proposed model, both the direct and indirect effects of the full model, which contains all variables, including $\mathrm{CB}$, social reflection which comprises two dimensions of safety perspective and work attitude, and safety behavior, were examined using AMOS21.

Model 4 in Table 8 indicates that the coefficient value of the direct effect of $\mathrm{CB}$ on safety behavior was not significant at the 0.05 level. The $\mathrm{H} 1$ postulated that $\mathrm{CB}$ has a positive effect on safety behavior is not supported. However, $\mathrm{CB}$ had the indirect effect coefficient value of 0.44 , it was the effect of social reflection derives from the dimensions of safety perspective and work attitude. The result provided evidence that $\mathrm{CB}$ exerts only an indirect effect on safety behavior via the social reflection factors of safety perspective and work attitude. Consequently, this study demonstrated that $\mathrm{CB}$ had a positive effect on safety behavior, and was further mediated by the combination of safety perspective and work attitude. The $\mathrm{H} 4$ was supported. 
Regarding with the standardized coefficients of each path of social reflection factors to safety behavior, SP to SB and WA to SB, were 0.43 and 0.23 , respectively. They were at 0.01 significant level and supported $\mathrm{H} 2$ that social reflection factors have a positive effect on safety behavior. With respecting to $\mathrm{H} 3$, the standardized coefficients of paths of CB to social reflection factors, $\mathrm{CB}$ to SP and $\mathrm{CB}$ to WA, were respective 0.60 and 0.79 . They were significant at 0.01 level and supported $\mathrm{H} 3$ that postulated that $\mathrm{CB}$ has a positive effect on social reflection factors as well.

\section{Conclusions and Recommendations}

\subsection{Conclusions}

OCB has been recognized as an important determinant to explain performance within organizations [3] [4] [5] [6] [7]. OCB seems to constitute an effective criterion to screen applicants prior to entering an organization. Extant literature [3] [4] [5] [6] [7] [14] relating to OCB focused on collecting data from members within the organization, which were considered as spot data, and employees had joined their organizations for a period of time. According to previous studies [4] [8]-[14] [17] [18], behavior is cultivated by culture, education, personality, and leadership from childhood onwards. Accordingly, all employees before entering an organization have already formed solid CB through long-term interactions with the environment. Organizations would like to recruit the best and most appropriate people to join their organization, to create a good organization climate and to achieve consistently excellent performance. Therefore, this study aimed to elucidate the role of CB to affect safety behavior and determine effective criteria to assist human resource managers to recruit optimal employees to create a complete and effective environment for their organization.

Theoretically, this study highlighted the role of CB in explaining the occurrence of safety behaviors. Moreover, an important question has been answered with regard to the effect of $\mathrm{CB}$ on safety behavior, i.e., "Does CB directly from safety behavior?" Further, the research illustrated how CB influences safety behaviors within the organization. In particular, this study provided evidence for the moderating/mediating effect of social reflection, i.e., safety perspective and work attitude, on the relationship between $\mathrm{CB}$ and safety behavior. To the best of our knowledge, this is the first study to provide empirical evidence for the role of $\mathrm{CB}$ in explaining safety behavior in general life.

\subsection{Theoretical and Managerial Implications}

A number of important findings have emerged from the study that offers both theoretical and managerial implications. First, a significant contribution of this study is the empirical testing of theoretical assumptions in the extant literature pertaining to the influence of $\mathrm{CB}$ on safety behavior. $\mathrm{CB}$ is demonstrated to have an insignificant direct impact on safety behavior. This finding indicates the role that CB plays in cultivating safety behavior. Indeed, it still interacts with the en- 
vironment in general life. An organization should therefore recruit employees with good $\mathrm{CB}$ to form a basis of $\mathrm{OCB}$, as well as support management to cultivate good OCB. Safety behavior is usually assured when people exhibit good CB. The study also indicated that safety behavior was separately modulated by safety perspective and work attitude, and safety behavior was mediated by these two external factors when they were combined. The significant impact of safety perspective and work attitude on safety behavior implies that the environment plays a key role in augmenting CB. The study also revealed that safety perspective and work attitude, as social reflection factors, were significantly influenced by $\mathrm{CB}$. This finding strongly suggests that $\mathrm{CB}$ can generate a safety perspective and work attitude in general life.

\subsection{Study Limitations and Future Research}

This study provided empirical evidence for the influence of CB on safety behavior in life. However, a number of limitations of the study should be noted, which then suggest directions for future research. First, this study specifically focused on collecting the perception of respondents at different life stage of maritime domain, it provided an easy way to complete the study and might cause bias in the research as well. Future studies might evaluate the effects of $\mathrm{CB}$ in other domains, such as logistics, high technology, or services, to verify the theory discovered in this study. Second, this study was based on a survey similar to a longitudinal study to assess $\mathrm{CB}$ and the promotion of performance at different stages of life. However, it could not conclusively determine individual change. In order to address this gap, future research could conduct a longitudinal study [70] [71]. Third, this study focused on the effect of CB based on respondents' self-reported behavior, but it did not verify the time point of greatest influence. Since organizations aim to improve their performance, future research should consider relationships between $\mathrm{CB}$, $\mathrm{OCB}$, organization culture, management systems, and their impacts on performance. A more comprehensive understanding of factors influencing performance could help to recruit the most appropriate people and implement optimal management practices within the organization. Finally, the collected data obtained from self-reported safety behaviors and perceptions of CB may have been subject to bias due to respondents' reluctance to report actual behavior. A potential social desirability bias or response set effect should therefore be considered. To address this, further research might measure respondents' behaviors by actual observation.

\section{Conflicts of Interest}

The authors declare no conflicts of interest regarding the publication of this paper.

\section{References}

[1] Barnard, C.I. (1938) The Functions of the Executive. Harvard University Press, 
Cambridge.

[2] Bolino, M.C., Turnley, W.H. and Bloodgood, J.M. (2002) Citizenship Behavior and the Creation of Social Capital in Organizations. Academy of Management Review, 27, 505-522. https://doi.org/10.5465/amr.2002.7566023

[3] Podsakoff, N.P., Whiting, S.W., Podsakoff, P.M. and Blume, B.D. (2009) Individualand Organizational-Level Consequences of Organizational Citizenship Behaviors: A Meta-Analysis. Journal of Applied Psychology, 94, 122-141. https://doi.org/10.1037/a0013079

[4] Borman, W.C., Penner, L.A., Allen, T.D. and Motowidlo, S.J. (2001) Personality Predictors of Citizenship Performance. International Journal of Selection and Assessment, 9, 52-69. https://doi.org/10.1111/1468-2389.00163

[5] Davila, M.C. and Finkelstein, M.A. (2010) Predicting Organizational Citizenship Behavior from the Functional Analysis and Role Identity Perspectives: Further Evidence in Spanish Employees. The Spanish Journal of Psychology, 13, 277-283. https://doi.org/10.1017/S1138741600003851

[6] Khiabani, M.M., Abdizadeh, M. and Baroto, M.B. (2014) Implementation of Organizational Citizenship Behavior Model in the Iranian Healthcare Industry. Wulfenia Journal, 21, 85-106.

[7] Lestari, E.R. and Ghaby, N.K.F. (2018) The Influence of Organizational Citizenship Behavior (OCB) on Employee's Job Satisfaction and Performance. Jurnal Teknologi dan Manajemen Agroindustri, 7, 116-123. https://doi.org/10.21776/ub.industria.2018.007.02.6

[8] Hofstede, G. (1981) Culture and Organizations. International Studies of Management and Organization, 10, 15-41. https://doi.org/10.1080/00208825.1980.11656300

[9] Hofstede, G. (1984) Culture's Consequences: International Differences in WorkRelated Values. Abridged Edition, Sage, Beverly Hills.

[10] Cohen, A. and Avrahami, A. (2006) The Relationship between Individualism, Collectivism, the Perception of Justice, Demographic Characteristics and Organizational Citizenship Behavior. Service Industries Journal, 26, 889-901. https://doi.org/10.1080/02642060601011707

[11] Lin, L. and Ho, Y. (2010) Guanxi and OCB: The Chinese Cases. Journal of Business Ethics, 96, 285-298. https://doi.org/10.1007/s10551-010-0465-6

[12] Mole, N. (1995) Mind Your Manners: Managing Cultural Clash in the Single European Market. Nicholas Brealey, London.

[13] Schein, E.H. (1992) Organizational Culture and Leadership: A Dynamic View. 2nd Edition, Jossey-Bass, San Francisco.

[14] Fleeson, W. (2001) Toward a Structure- and Process-Integrated View of Personality: Traits as Density Distributions of States. Journal of Personality and Social Psychology, 80, 1011-1027. https://doi.org/10.1037/0022-3514.80.6.1011

[15] Fleeson, W. (2007) Situation-Based Contingencies Underlying Trait-Content Manifestation in Behavior. Journal of Personality, 75, 825-862. https://doi.org/10.1111/j.1467-6494.2007.00458.x

[16] Fleeson, W. and Gallagher, P. (2009) The Implications of Big-Five Standing for the Distribution of Trait Manifestation in Behavior: Fifteen Experience-Sampling Studies and a Meta-Analysis. Journal of Personality and Social Psychology, 97, 10971114. https://doi.org/10.1037/a0016786

[17] Moskowitz, D.S. and Zuroff, D.C. (2004) Flux, Pulse, and Spin: Dynamic Additions to the Personality Lexicon. Journal of Personality and Social Psychology, 86, 880-893. 
https://doi.org/10.1037/0022-3514.86.6.880

[18] Lu, C.S. and Tsai, C.L. (2010) The Effect of Safety Climate on Seafarers' Safety Behaviors in Container Shipping. Accident Analysis and Prevention, 42, 1999-2006. https://doi.org/10.1016/j.aap.2010.06.008

[19] Lu, C.S. and Tsai, C.L. (2008) The Effects of Safety Climate on Vessel Accidents in the Container Shipping Context. Accidents Analysis and Prevention, 40, 594-601. https://doi.org/10.1016/j.aap.2007.08.015

[20] Bateman, T.S. and Organ, D.W. (1983) Job Satisfaction and the Good Soldier: The Relationship between Affect and Employee "Citizenship." Academy of Management Journal, 26, 587-595. https://doi.org/10.2307/255908

[21] Ertürk, A., Yılmaz, C. and Ceylan, A. (2004) Promoting Organizational Citizenship Behaviors: Relative Effects of Job Satisfaction, Organizational Commitment, and Perceived Managerial Fairness. METU Studies in Development, 31, 89-210.

[22] Schnake, M. (1991) Organizational Citizenship: A Review, Proposed Model, and Research Agenda. Human Relations, 44, 735-759. https://doi.org/10.1177/001872679104400706

[23] Organ, D.W. (1988) Organizational Citizenship Behavior: The Good Soldier Syndrome. Lexington, Lexington.

[24] Organ, D.W. (1997) Organizational Citizenships Behavior: It's Construct Cleanup Time. Human Performance, 10, 85-97. https://doi.org/10.1207/s15327043hup1002_2

[25] Farh, J., Zhong, C. and Organ, D.W. (2004) Organizational Citizenship Behavior in the People's Republic of China. Organization Science, 15, 241-253. https://doi.org/10.1287/orsc.1030.0051

[26] George, J.M. and Brief, A.P. (1992) Feeling Good-Doing Good: A Conceptual Analysis of the Mood at Work-Organizational Spontaneity Relationship. Psychological Bulletin, 112, 310-329. https://doi.org/10.1037/0033-2909.112.2.310

[27] Katz, D. (1964) The Motivational Basis of Organizational Behavior. Behavioral Science, 9, 131-146. https://doi.org/10.1002/bs.3830090206

[28] Katz, D. and Kahn, R.L. (1966) The Social Psychology of Organizations. Wiley, New York.

[29] Podsakoff, P.M., MacKenzie, S.B., Paine, J.B. and Bachrach, D.G. (2000) Organizational Citizenship Behaviors: A Critical Review of the Theoretical and Empirical Literature and Suggestions for Future Research. Journal of Management, 26, 513-563. https://doi.org/10.1177/014920630002600307

[30] Didla, S., Mearns, K. and Flin, R. (2009) Safety Citizenship Behaviour: A Proactive Approach to Risk Management. Journal of Risk Research, 12, 475-483. https://doi.org/10.1080/13669870903041433

[31] MacKenzie, S.B., Podsakoff, P.M. and Fetter, R. (1993) The Impact of Organizational Citizenship Behavior on Evaluations of Salesperson Performance. Journal of Marketing, 57, 70-80. https://doi.org/10.1177/002224299305700105

[32] Konovsky, M.A. and Organ, D.W. (1996) Dispositional and Contextual Determinants of Organizational Citizenship Behavior. Journal of Organizational Behavior, 17, 253-266. https://doi.org/10.1002/(SICI)1099-1379(199605)17:3<253::AID-JOB747>3.0.CO;2-Q

[33] DiPaola, M.F. and Tschannen-Moran, M. (2001) Organizational Citizenship Behavior in Schools and Its Relationship to School Climate. Journal of School Leadership, 11, 424-447. https://doi.org/10.1177/105268460101100503 
[34] Judge, T.A., Simon, L.S., Hurst, C. and Kelley, K. (2014) What I Experienced Yesterday Is Who I Am Today: Relationship of Work Motivations and Behaviors to Within-Individual Variation in the Five-Factor Model of Personality. Journal of Applied Psychology, 99, 199-221. https://doi.org/10.1037/a0034485

[35] Miles, E.L., Underdal, A., Andresen, S., Wettestad, J., Skjærseth, J.B. and Carlin, E.M. (2002) Environmental Regime Effectiveness: Confronting Theory with Evidence. MIT Press, Cambridge. https://doi.org/10.7551/mitpress/2784.001.0001

[36] Rhoades, L. and Eisenberger, R. (2002) Perceived Organizational Support: A Review of the Literature. Journal of Applied Psychology, 87, 698-714. https://doi.org/10.1037/0021-9010.87.4.698

[37] Tziner, A. and Sharoni, G. (2014) Organizational Citizenship Behavior, Organizational Justice, Job Stress, and Work Family Conflict: Examination of Their Interrelationships with Respondents from a Non-Western Culture. Journal of Work and Organizational Psychology, 30, 35-42. https://doi.org/10.5093/tr2014a5

[38] LePine, J.A., Erez, A. and Johnson, D.E. (2002) The Nature and Dimensionality of Organizational Citizenship Behavior: A Critical Review and Meta-Analysis. Journal of Applied Psychology, 87, 52-65. https://doi.org/10.1037/0021-9010.87.1.52

[39] Williams, L.J. and Anderson, S.E. (1991) Job Satisfaction and Organizational Commitment as Predictors of Organizational Citizenship and In-Role Behaviors. Journal of Management, 17, 601-617. https://doi.org/10.1177/014920639101700305

[40] Locke, J. (1996) Some Thoughts Concerning Education and of the Conduct of the Understanding. Hackett, Indianapolis.

[41] Reid, B. (1993) “But We're Doing It Already!" Exploring a Response to the Concept of Reflective Practice in Order to Improve Its Facilitation. Nurse Education Today, 13, 305-309. https://doi.org/10.1016/0260-6917(93)90058-A

[42] Conner, M., Lawton, R., Parker, D., Chorlton, K., Manstead, A.S.R. and Stradling, S. (2007) Application of the Theory of Planned Behaviour to the Prediction of Objectively Assessed Breaking of Posted Speed Limits. British Journal of Psychology, 98, 429-453. https://doi.org/10.1348/000712606X133597

[43] Isen, A.M. and Levin, P.F. (1972) Effect of Feeling Good on Helping: Cookies and Kindness. Journal of Personality and Social Psychology, 21, 384-388. https://doi.org/10.1037/h0032317

[44] Kolb, D.A. (1984) Experiential Learning: Experience as the Source of Learning and Development. 2nd Edition, Prentice-Hall, Upper Saddle River.

[45] McNiff, J. and Whitehead, J. (2000) Action Research in Organizations. Routledge, New York.

[46] Morrison, E.W. (1994) Role Definitions and Organizational Citizenship Behavior: The Importance of the Employee's Perspective. Academy of Management Journal, 37, 1543-1567. https://doi.org/10.2307/256798

[47] Bolino, M.C., Hsiung, H.H., Harvey, J. and LePine, J.A. (2015) Well, I'm Tired of Tryin! Organizational Citizenship Behavior and Citizenship Fatigue. Journal of Applied Psychology, 100, 56-74. https://doi.org/10.1037/a0037583

[48] Kacmar, K.M., Bachrach, D.G., Harris, K.J., Shaw, J.D. and Noble, D. (2011) The Moderating Effect of Impression Management on the Organizational Citizenship Behavior-Voluntary Turnover Relationship. The Journal of Applied Management and Entrepreneurship, 16, 4-26.

[49] Niehoff, B.P. and Moorman, R.H. (1993) Justice as a Moderator of the Relationship between Methods of Mentoring and Organizational Citizenship Behavior. Academy 
of Management Journal, 36, 527-556. https://doi.org/10.2307/256591

[50] Schon, D.A. (1983) The Reflective Practitioner: How Professionals Think in Action. Basic Books, New York.

[51] Churchill, G.A. and Iacobucci, D. (2004) Marketing Research: Methodological Foundations. 9th Edition, Thomson, South-Western.

[52] Hair, J., Black, W., Babin, B., Anderson, R. and Tatham, R. (2006) Multivariate Data Analysis. 6th Edition, Pearson Prentice Hall, Upper Saddle River.

[53] Coakes, S.J. and Steed, L.G. (2007) SPSS: Analysis without Anguish: Version 14.0 for Windows. John Wiley \& Sons Australia Ltd., Brisbane.

[54] Lauder, W., Reynolds, W., Reilly, V. and Angus, N. (2000) The Development and Testing of the Mental Health Problems, Perception Questionnaire. Journal of Psychiatric and Mental Health Nursing, 7, 221-226.

https://doi.org/10.1046/j.1365-2850.2000.00270.x

[55] Nunnally, J.C. (1978) Psychometric Theory. 2nd Edition, McGraw-Hill, New York.

[56] Segars, A. (1997) Assessing the Unidimensionality of Measurement: A Paradigm and Illustration within the Context of Information Systems Research. Omega-International Journal of Management Science, 25, 107-121. https://doi.org/10.1016/S0305-0483(96)00051-5

[57] Litwin, M.S. (1995) How to Measure Survey Reliability and Validity. Sage Publications, Thousand Oaks. https://doi.org/10.4135/9781483348957

[58] Churchill, G.A. and Peter, J.P. (1984) Research Design Effects on the Reliability of Rating Scales: A Meta-Analysis. Journal of Marketing Research, 21, 360-375. https://doi.org/10.1177/002224378402100402

[59] Hurley, A.E., Scandura, T.A., Schriesheim, C.A., Brannick, M.T., Seers, A., Vandenberg, R.J. and Williams, L.J. (1997) Exploratory and Confirmatory Factor Analysis: Guidelines, Issues, and Alternatives. Journal of Organizational Behavior, 18, 667-683. https://doi.org/10.1002/(SICI)1099-1379(199711)18:6<667::AID-JOB874>3.0.CO;2-T

[60] Gorsuch, R.L. (1983) Factor Analysis. 2nd Edition, Erlpaum, Hillsdale.

[61] Norusis, M.J. (1985) SPSSX Advanced Statistics Guide. McGraw-Hill, New York.

[62] Griethuijsen, R.A.L.F., Eijck, M.W., Haste, H., Brok, P.J., Skinner, N.C. and Mansour, N. (2014) Global Patterns in Students' Views of Science and Interest in Science. Research in Science Education, 45, 581-603. https://doi.org/10.1007/s11165-014-9438-6

[63] Bentler, P.M. and Bonnett, D.G. (1980) Significant Tests and Goodness of Fit in the Analysis of Covariance Structure. Psychological Bulletin, 88, 588-606. https://doi.org/10.1037//0033-2909.88.3.588

[64] Shah, R. and Goldstein, S.M. (2006) Use of Structural Equation Modeling in Operations Management Research: Looking Back and Forward. Journal of Operations Management, 24, 148-169. https://doi.org/10.1016/j.jom.2005.05.001

[65] Hu, L. and Bentler, P.M. (1998) Fit Indices in Covariance Structure Modeling: Sensitivity to Under-Parameterized Model Misspecification. Psychological Methods, 3, 424-453. https://doi.org/10.1037/1082-989X.3.4.424

[66] Koufteros, X.A. (1999) Testing a Model of Pull Production: A Paradigm for Manufacturing Research Using Structural Equation Modeling. Journal of Operations Management, 17, 467-488. https://doi.org/10.1016/S0272-6963(99)00002-9

[67] Lievens, F. and Anseel, F. (2004) Confirmatory Factor Analysis and Invariance of an 
Organizational Citizenship Behavior Measure across Samples in a Dutch-Speaking Context. Journal of Occupational and Organizational Psychology, 77, 299-306. https://doi.org/10.1348/0963179041752727

[68] Medsker, G.J., Williams, L.J. and Holahan, P.J. (1994) A Review of Current Practices for Evaluating Causal-Models in Organizational-Behavior and Human-Resources Management Research. Journal of Management, 20, 439-464. https://doi.org/10.1177/014920639402000207

[69] Byrne, B.M. (2001) Structural Equation Modeling with AMOS: Basic Concepts, Applications, and Programming. Lawrence Erlbaum Associates, Mahwah.

[70] Mearns, K., Whitaker, S.M. and Flin, R. (2001) Benchmarking Safety Climate in Hazardous Environments: A Longitudinal, Interorganizational Approach. Risk Analysis, 21, 771-786. https://doi.org/10.1111/0272-4332.214149

[71] Hoonakker, P., Loushine, T., Carayon, P., Kallman, J., Andrew, K.A., Michael, J. and Smith, M.J. (2005) The Effect of Safety Initiatives on Safety Performance: A Longitudinal Study. Applied Ergonomics, 36, 461-469.

https://doi.org/10.1016/j.apergo.2004.07.006 


\section{Appendix}

Table A1. Research questionnaire.

\begin{tabular}{|c|c|c|c|c|c|c|}
\hline & $\begin{array}{l}\text { Statements of measures } \\
\text { (“1” = Strongly Disagree; } \\
\text { “5” = Strongly Agree) }\end{array}$ & $\begin{array}{l}\text { Strongly } \\
\text { Disagree }\end{array}$ & Disagree & $\begin{array}{l}\text { Neither } \\
\text { Agree Nor } \\
\text { Disagree }\end{array}$ & Agree & $\begin{array}{c}\text { Strongly } \\
\text { Agree }\end{array}$ \\
\hline 1 & $\begin{array}{l}\text { I support coworkers/classmates } \\
\text { who have problems at work. }\end{array}$ & $\square$ & $\square$ & $\square$ & $\square$ & $\square$ \\
\hline 2 & $\begin{array}{l}\text { I take time out of my day to help } \\
\text { train newcomers. }\end{array}$ & $\square$ & $\square$ & $\square$ & $\square$ & $\square$ \\
\hline 3 & $\begin{array}{l}\text { I share my knowledge and expertise } \\
\text { with other coworkers. }\end{array}$ & $\square$ & $\square$ & $\square$ & $\square$ & $\square$ \\
\hline 4 & $\begin{array}{l}\text { I talk to other coworkers before } \\
\text { taking actions that might affect them. }\end{array}$ & $\square$ & $\square$ & $\square$ & $\square$ & $\square$ \\
\hline 5 & $\begin{array}{l}\text { I engage in self-improvement to } \\
\text { enhance the quality of work knowledge. }\end{array}$ & $\square$ & $\square$ & $\square$ & $\square$ & $\square$ \\
\hline 6 & $\begin{array}{l}\text { I propose my own ideas and suggestions } \\
\text { to enhance the work efficient. }\end{array}$ & $\square$ & $\square$ & $\square$ & $\square$ & $\square$ \\
\hline 7 & $\begin{array}{l}\text { I actively attend activities that are } \\
\text { not required, but that help enhance } \\
\text { the image of the organization. }\end{array}$ & $\square$ & $\square$ & $\square$ & $\square$ & $\square$ \\
\hline 8 & $\begin{array}{l}\text { I actively express opinions that are } \\
\text { not required, but that help the } \\
\text { organization functions. }\end{array}$ & $\square$ & $\square$ & $\square$ & $\square$ & $\square$ \\
\hline 9 & $\begin{array}{l}\text { I consider that all members are } \\
\text { responsible for the development and } \\
\text { reputation of the organization. }\end{array}$ & $\square$ & $\square$ & $\square$ & $\square$ & $\square$ \\
\hline 10 & $\begin{array}{l}\text { I keep abreast of changes/developments } \\
\text { in the organization. }\end{array}$ & $\square$ & $\square$ & $\square$ & $\square$ & $\square$ \\
\hline 11 & $\begin{array}{l}\text { I make the necessary improvements } \\
\text { if the critique is justified. }\end{array}$ & $\square$ & $\square$ & $\square$ & $\square$ & $\square$ \\
\hline 12 & $\begin{array}{l}\text { I focus on the positive aspects of } \\
\text { my responsibility. }\end{array}$ & $\square$ & $\square$ & $\square$ & $\square$ & $\square$ \\
\hline 13 & I do not complain about trivial matters. & $\square$ & $\square$ & $\square$ & $\square$ & $\square$ \\
\hline 14 & I usually tolerate minor imperfections. & $\square$ & $\square$ & $\square$ & $\square$ & $\square$ \\
\hline 15 & $\begin{array}{l}\text { I conform to all obligations with } \\
\text { great care. }\end{array}$ & $\square$ & $\square$ & $\square$ & $\square$ & $\square$ \\
\hline 16 & $\begin{array}{l}\text { I consider it as a chance of } \\
\text { self-enhance when I encounter a } \\
\text { problem during work. }\end{array}$ & $\square$ & $\square$ & $\square$ & $\square$ & $\square$ \\
\hline 17 & $\begin{array}{l}\text { I consider it as challenge when I } \\
\text { encounter a problem during work. }\end{array}$ & $\square$ & $\square$ & $\square$ & $\square$ & $\square$ \\
\hline 18 & $\begin{array}{l}\text { I always do my best to complete } \\
\text { my assignment. }\end{array}$ & $\square$ & $\square$ & $\square$ & $\square$ & $\square$ \\
\hline 19 & I always complete my work efficiently. & $\square$ & $\square$ & $\square$ & $\square$ & $\square$ \\
\hline
\end{tabular}




\section{Continued}

\begin{tabular}{|c|c|c|c|c|c|c|}
\hline 20 & I always complete my work by due time. & $\square$ & $\square$ & $\square$ & $\square$ & $\square$ \\
\hline 21 & $\begin{array}{l}\text { It is important to wear properly } \\
\text { personal protective equipment when I } \\
\text { work/ exercise (biking or skating). }\end{array}$ & $\square$ & $\square$ & $\square$ & $\square$ & $\square$ \\
\hline 22 & $\begin{array}{l}\text { It is important to ensure workplace } \\
\text { safety while I working }\end{array}$ & $\square$ & $\square$ & $\square$ & $\square$ & $\square$ \\
\hline 23 & $\begin{array}{l}\text { It is important to report any risks or } \\
\text { hazards that I experience or witness. }\end{array}$ & $\square$ & $\square$ & $\square$ & $\square$ & $\square$ \\
\hline 24 & $\begin{array}{l}\text { It is important to look closely the safety } \\
\text { of coworkers while working together. }\end{array}$ & $\square$ & $\square$ & $\square$ & $\square$ & $\square$ \\
\hline 25 & $\begin{array}{l}\text { It is important to wear helmet } \\
\text { when I ride a bicycle/motorcycle. }\end{array}$ & $\square$ & $\square$ & $\square$ & $\square$ & $\square$ \\
\hline 26 & $\begin{array}{l}\text { It is important to secure seat belt } \\
\text { when I sit in a car. }\end{array}$ & $\square$ & $\square$ & $\square$ & $\square$ & $\square$ \\
\hline 27 & $\begin{array}{l}\text { I reduce speed as I approaching to } \\
\text { the block even without any traffic. }\end{array}$ & $\square$ & $\square$ & $\square$ & $\square$ & $\square$ \\
\hline 28 & I always follow the traffic regulation. & $\square$ & $\square$ & $\square$ & $\square$ & $\square$ \\
\hline 29 & $\begin{array}{l}\text { I always follow the instruction } \\
\text { of traffic signal. }\end{array}$ & $\square$ & $\square$ & $\square$ & $\square$ & $\square$ \\
\hline 30 & I always keep in the right traffic lane. & $\square$ & $\square$ & $\square$ & $\square$ & $\square$ \\
\hline
\end{tabular}

\section{General Information}

1) Gender:

$\square$ Male $\square$ Female

2) Age:

$\square<15 \square 16-20 \square 21-25 \square 26-30 \square 31-35 \square>35$

3) Education:

$\square$ Secondary school $\square$ High School $\square$ Collage/University $\square$ Graduated

4) Work condition now:

$\square$ No $\square$ Study in school $\square$ Work on shore $\square$ Serve onboard.

5) Specialized:

$\square$ No $\square$ Navigation $\square$ Engine $\square$ Others, Please specified

6) Sea age:

$\square<1 \square 1-3 \square 4-6 \square 6-9 \square 10-12 \square>13$

7) Where are you from?

$\square$ Northern Taiwan $\square$ Central Taiwan $\square$ Southern Taiwan $\square$ Eastern Taiwan $\square$ Others Please specified.

The End of the questionnaire. Thank you very much for your kindness. 